\title{
Islet Glucagon Cell Hyperplasia
}

National Cancer Institute

\section{Source}

National Cancer Institute. Islet Glucagon Cell Hyperplasia. NCI Thesaurus. Code C157458.

Hyperplasia of the alpha cells of the pancreas. 